\title{
Perforation of small intestine due to metastatic lung carcinoma
}

\author{
Shay Brikman, Elena Chertok, Guy Dori
}

Internal Medicine E, Emek Medical Center, Afula, Israel

\section{Correspondence to} Dr Guy Dori, guydo@clalit.org.il

Accepted 30 August 2018
D Check for updates

(c) BMJ Publishing Group Limited 2018. No commercial re-use. See rights and permissions. Published by BMJ.

\section{To cite: Brikman S,}

Chertok E, Dori G. BMJ Case Rep Published Online First: [please include Day Month Year]. doi:10.1136/bcr-2018225708

\section{DESCRIPTION}

A 66-year-old woman with a history of 40 packyear cigarette smoking and type II diabetes mellitus presented to the emergency department with unexplained weight loss and cough for a few weeks. These complaints constituted her first clinical manifestation. Physical examination was notable for diffuse abdominal tenderness. Chest and abdominal films (figure 1) revealed a prominent round opaque lesion in the right lung (arrow) and a large amount of free air under diaphragms with air-fluid levels.

The patient underwent an urgent laparotomy for pneumoperitoneum. Perforation of the small intestine due to a malignant metastasis was detected. The patient underwent a wide resection of the small intestine with closed loop anastomosis. The biopsy specimen was consistent with poorly differentiated squamous cell lung carcinoma staining positively for PDL-1 receptor. Her postoperative course was malignant, including: superior vena cava syndrome treated with a stent, redo operation due to eventration and nosocomial pneumonia, and she was transferred to an oncologic centre for palliative mediastinal radiation. The patient succumbed 6 weeks after admission.

The most common malignancy accounting for gastrointestinal perforation is lung cancer, which

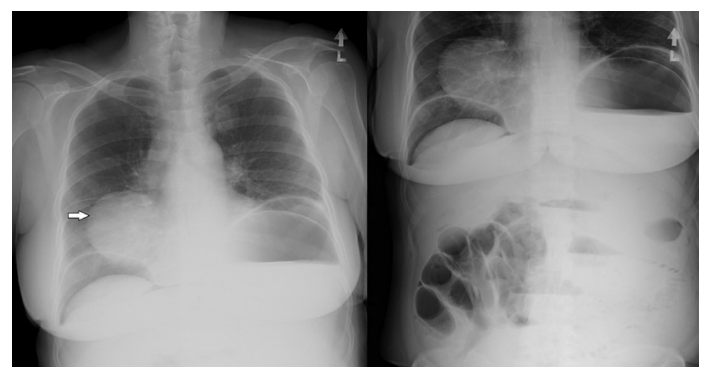

Figure 1 Upright chest (left) and abdominal (right) films demonstrating round opaque lesion (arrow) and free air under diaphragms and levels of fluid in the stomach and intestine. tends to primarily involve the small bowel and is usually accompanied by a small amount of free air. ${ }^{1}$ Lung cancer frequently metastasises to brain, liver, bones and adrenals. However, small intestine metastasis of primary lung cancer may occur in up to $10.7 \%$ of the cases. It has also been reported that about $30 \%$ of intestinal metastases of primary lung cancer were squamous cell carcinoma by pathology subtype. Perforation of the small bowel by metastasis of lung carcinoma is a poor prognostic indicator with median survival of 1.5 months. ${ }^{2}$

\section{Learning points}

Peritonitis in a heavy smoker patient with unexplained ongoing weight loss may be due to intestinal perforation caused by remote metastasis.

- The prognosis of a patient with an intestinal perforation due to lung cancer metastasis is poor.

Contributors SB suggested reporting the case, acquired the relevant data, interpreted the data and reviewed the literature. EC acquired the relevant data, interpreted the data and researched the literature. GD studied the literature and wrote the manuscript. All authors reviewed and approved the manuscript.

Funding The authors have not declared a specific grant for this research from any funding agency in the public, commercial or not-for-profit sectors.

Competing interests None declared.

Patient consent Next of kin consent obtained.

Provenance and peer review Not commissioned; externally peer reviewed.

\section{REFERENCES}

1 Kim SW, Kim HC, Yang DM. Perforated tumours in the gastrointestinal tract: $\mathrm{CT}$ findings and clinical implications. Br J Radiol 2012;85:1307-13.

2 Di JZ, Peng JY, Wang ZG. Prevalence, clinicopathological characteristics, treatment, and prognosis of intestinal metastasis of primary lung cancer: a comprehensive review. Surg Oncol 2014;23:72-80. 
Copyright 2018 BMJ Publishing Group. All rights reserved. For permission to reuse any of this content visit http://group.bmj.com/group/rights-licensing/permissions.

BMJ Case Report Fellows may re-use this article for personal use and teaching without any further permission.

Become a Fellow of BMJ Case Reports today and you can:

- Submit as many cases as you like

- Enjoy fast sympathetic peer review and rapid publication of accepted articles

Access all the published articles

- Re-use any of the published material for personal use and teaching without further permission

For information on Institutional Fellowships contact consortiasales@bmjgroup.com

Visit casereports.bmj.com for more articles like this and to become a Fellow 